\title{
Challenges in Reshaping the Sectoral Innovation System of the Chinese Automobile Industry
}

\author{
Kaidong Feng and Junran Li
}

\begin{abstract}
The aim of this chapter is to analyze and review the progress of China's technological innovation in the automobile sector. First, the structure of the Chinese automobile industry and its relevant innovation system are characterized by multiple camps of actors - namely, multinationals, large state-owned firms, and new local entrants - with different business goals, innovation objectives, and technological capabilities. Secondly, different camps of actors entered the Chinese automobile sector in different phases of the developmental strategies of China. Thus, China's policy transition during 2005-2006 to indigenous innovation created a drive among all indigenous firms toward technology and product development, and the demand for electrical vehicles created a valuable opportunity. However, the internal dynamics or rigidities of the different camps of actors appear to show significant path resistance. Only a persistent push by the Chinese government for indigenous innovation will enable a total structural change, particularly involving the large state-owned enterprises.
\end{abstract}

\section{Keywords}

Automobile industry · Indigenous innovation · Trading market for technology • Patent $\cdot$ SOE

K. Feng $(\bowtie) \cdot$ J. Li

School of Government, Peking University, Beijing, China

e-mail: k.feng@pku.edu.cn 
Peter Drucker termed the automotive industry "the industry of industries." Indeed, the automotive industry around the world has played a vital role in driving the industrialization of large modern economies. Naturally, the Chinese society also expects this to be the case. This chapter discusses the growth and development of the Chinese car-making industry in two fields: "traditional" internal combustion engine (ICE) cars, also known as fossil fuel vehicles (FFVs), and electric vehicles (EVs). We also highlight the significant differences in research and development (R\&D) between the two groups of major local producers: the traditional large backbone state-owned enterprises (backbone SOEs) ${ }^{2}$ and those that have entered this industry only after the second half of the 1990s (new local entrants; see Appendix 1 for a list of firms). We found that there are significant differences in the technological progress of the Chinese car-making industry between the two enterprise groups, and the differences are induced by a historical policy structure. Furthermore, there are also significant differences in the innovation achievements of Chinese enterprises in the fields of FFVs and EVs, which are dependent on technological characteristics and maturity.

On the whole, although China has become the world's largest automotive producer and consumer, the indigenous car-makers of China are far from being global technology leaders. However, the developmental pattern of China's indigenous carmaking industry shows positive transformation. Thus, the previous dominant strategy of the automobile firms, involving the assemblage of imported foreign designs only, has already given way to the strategy of indigenous innovation. Despite being a latecomer, China has started to develop products and technologies locally, and Chinese manufacturers are gradually becoming competitive in the global automobile market during the rise of EVs.

\section{Introduction: Two Camps and Two Catching-Up Trajectories in One Industry}

For the Chinese society, the car-making industry is always an appealing topic. On the one hand, this industry had long been left aside by the state planning system. Due to the emphasis on industrial capital goods rather than consumer goods, the passenger vehicle sector (including car-making) was not listed by the central planner as a key industry for decades, which is a typical Gerschenkronian strategy of industrialization. ${ }^{3}$ It was not until China's introduction of "the 1994 automobile

\footnotetext{
${ }^{1}$ Drucker, Peter F. (1946) Concept of the Corporation, New York: John Day

${ }^{2}$ The compound term "backbone SOEs" in this chapter refers to large SOEs directly influenced by the central government. "Backbone" indicates large size, and a critical role within their corresponding sectoral systems, particularly in the previous central planning era. Even in the current reform era, through direct oversight by the State-owned Asset Supervision and Administration Commission (SASAC), the central government still influences their strategy making. By contrast, the term "SOE" in this chapter is defined by the ownership of a firm, in which some state investors own significant stock shares.

${ }^{3}$ The Gerschenkronian strategy refers to a typical state-led pattern of industrialization: The state plays a critical role in resource mobilization in society and pinpoints the selected areas for strategic
} 
industry policy" that car-making has been recognized as a national pillar industry along with the entire sector of automobile manufacturing. Nevertheless, the car industry has been of high interest to the Chinese society for decades. The transformation of China's developmental strategy, from emphasizing "trading market for technology (TMFT)" to focusing on indigenous innovation, was triggered by public dissatisfaction with the pace of technical progress in the domestic car-making industry. The policy transformation was marked by the "National Medium- and Long-term Program for Science and Technology Development (2006-2020) Outline," which was promulgated in 2006. That is to say, the concern over the lack of technological capability in the car-making industry has promoted the transition of development strategy at the national level. This concern also has pushed the industrial regulator to change its previous practices, allowing a group of new, local, innovative firms to enter the industry.

However, even with the current favorable environment, which supports indigenous innovation, it remains challenging for late-coming firms to accumulate technical competitive advantage in a global industry consisting of a large number of complex technologies and components. The following four factors determine the extent to which technical capability accumulates in the automotive industry, thereby increasing the difficulty for the latecomers to catch up in technology.

First, the car-making industry is closely related to many other industries and technology domains, such as the steel, machine tool, and electronics industries and materials engineering. Manufacturing in this industry also relies heavily on the capability of the national industrial system. Second, much of the technical knowledge in the automotive industry is tacit in nature and often protected by intellectual property (IP) rights. This makes it difficult for latecomers to directly imitate complicated technologies of the first-movers. Third, the dominant design of a car was primarily determined in the 1920s. ${ }^{4}$ Although some new technologies, such as materials and electronics, have been gradually added to the dominant design over the century that followed, and the value created by these new technologies is becoming more and more important, these new technologies do not change the core design. Thus, the relevant innovations are competence-enhancing rather than competence-destroying for the incumbents., ${ }^{5,6}$ Finally, a great deal of key knowledge of car-making is highly embedded in specialized social networks

\footnotetext{
investment. The strategy implemented by Korea during the Park Chung-Hee administration (19611978) is a representative case. For detailed discussion, see Amsden, Alice H. (1989) Asia's Next Giant: South Korea and Late Industrialization, New York: Oxford University Press.

${ }^{4}$ Clark, Kim B. (1985) "The interaction of design hierarchies and market concepts in technological evolution." Research Policy, 14(5): 235-251

${ }^{5}$ Tushman, Michael L. and Philip Anderson (1986) "Technological discontinuities and organizational environments." Administrative Science Quarterly, 31:439-465

${ }^{6}$ Anderson, Philip and Michael L. Tushman (1990) Technological discontinuities and dominant designs: a cyclical model of technological change. Administrative Science Quarterly, 35: 604-633
} 
among the collaborating firms. ${ }^{7}$ This type of knowledge is difficult to be transferred as a simple sum of information, and difficult to be withheld by individual participants, which greatly enhances the stickiness of knowledge, making it hard for the latecomer to grasp easily. ${ }^{8}$

In short, unlike a science-based industry, the car-making industry is manufacturingintensive and scale-intensive. ${ }^{9}$ In this industry, key knowledge is embedded in manufacturing or design experience, and does not appear in explicit forms such as utility and invention patents. Although patents are becoming increasingly important, a vast majority of "know-how" or "know-whom" kind of knowledge in this industry cannot be mastered by a firm through the acquisition of patents or patent licenses. Indeed, the technical trade and R\&D collaboration of many core businesses are through engineering services, design transfer (usually including engineering services), and component supplies. Hence, capacity building in this industry is a long-term process and may take many decades for latecomers, although imitation and reverse-engineering are emphasized as the methods for learning technology. ${ }^{10}$

Technological catching-up by domestic Chinese manufacturers in the FFV industry highlights a two-sided story. On one hand, aided by national policy, a group of new entrants have successfully entered the mass automobile market by providing consumers with more cost-effective cars, gaining a relatively stable living space and continuing to climb the technical ladder. The success of these firms and the rapid expansion of China's car-making industry have proved the policy case for indigenous innovation. On the other hand, established Chinese auto manufacturers have faced difficulties in developing cutting-edge technologies and competing in the high-end market. The significantly accumulative characteristics of the industry in capacity building have left the indigenous Chinese manufacturers behind global auto industry leaders. Thus, while the domestic market share held by new local entrants has been stable for a long time at about 30\%, the Chinese automakers have been able to penetrate only the middle- and low-end segments of the third-world markets, though they are increasingly being recognized globally.

Development of EVs has created an alternative landscape for the Chinese government as well as the indigenous Chinese firms. EVs are returning to the mass market because of the need for energy conservation and environmental protection, and this change is to some extent an innovation with technological discontinuities. ${ }^{11}$ In EVs,

\footnotetext{
${ }^{7}$ Clark, Kim B. and Takahiro Fujimoto (1991) Product Development Performance: Strategy, Organization, and Management in the World Automobile Industry. Boston, MA: Harvard Business School Press

${ }^{8}$ von Hippel, Eric (1998) "Sticky information" and the locus of problem solving: implications for innovation, In Alfred Chandler et al. (eds.), The Dynamic Firm, New York: Oxford University Press: 60-77

${ }^{9}$ Pavitt, Keith (1984) Sectoral patterns of technical change: towards a taxonomy and a theory. Research Policy 13(6): 343-374

${ }^{10} \mathrm{Kim}$, Linsu (1997) Imitation to Innovation: the dynamics of Korea's technological learning. Boston, Harvard Business School Press

${ }^{11}$ Tushman, Michael L. and Philip Anderson (1986) Technological discontinuities and organizational environments." Administrative Science Quarterly, 31:439-465
} 
motors and batteries are employed to replace the engines and gearboxes of the FFVs. New requirements for complex technologies have also emerged, such as for controlling the batteries. Moreover, compared to FFVs, EVs are better able to interface with computer-based technologies, such as AI, the mobile Internet, and cloud computing. This has induced an explosive development of ICT technology applications on the car platform, creating an opportunity for China to pursue catch-up development. ${ }^{12}$ The Chinese government has tabled a range of battery research and production projects and has enacted policies to encourage investment in development and industrialization of EVs while subsidizing investments in infrastructure, especially a network of rechargeable devices. These measures have enabled China to overtake the USA as the world's largest producer and consumer of EVs in 2015.

Compared to the incumbents in China's domestic car market, including backbone SOEs and multinationals, as well as the joint ventures (JVs) between these two groups of firms, the new local entrants also have more enthusiasm in developing EVs. Because they are challengers to the original pattern, they look forward to building their own competitive advantage by seizing this opportunity. They are the main driving force for the development of China's EV industry, followed by some new subordinate companies set up by backbone SOEs due to the pressure of indigenous innovation policy. In some areas of EVs, such as specific battery technologies and business models, Chinese innovation has reached the forefront of the world. This has paved the way for the Chinese automakers to become challengers in the global EV markets.

However, EVs are not radical innovations. Compared to an FFV, EV has revolutionized the engine and transmission modules, but many other modules of a passenger car, such as the bodywork design, chassis engineering, and security system, remain largely the same. More importantly, in terms of market reputation, consumers still follow traditions, perceiving the cars of multinational companies as higher quality compared to the Chinese cars. Also true in a developing country like China is that people associate the ownership of foreign-made, well-recognized global brands with social status. None of these factors is helpful to gain competitive advantage in the auto market for the new domestic Chinese entrants.

As a result, local Chinese firms also face difficulties in the EV sector, although much less so compared to the FFV sector. They have only captured some space in the middle- and low-end market segments, while multinationals such as Volkswagen, Toyota, Tesla, and BMW still dominate the high-end market. Also notable is the fact that though the EV market share of local firms may be increasing, the EV market pie itself is still very small compared to the size of the FFV market. This implies that local EV producers have difficulties quickly expanding scale through substantial economic gains from the market.

\footnotetext{
${ }^{12}$ Perez, Carlota and Luc Soete (1988) Catching up in technology: entry barriers and windows of opportunity. In: Technical Change and Economic Theory, eds. G. Dosi, C. Freeman, R. Nelson, G. Silverberg and L. Soete. London, Pinter: 458-479
} 


\section{Technological Catching-Up in FFV Sector}

\subsection{Through Strict Entry Regulation and TMFT}

Before China's national development strategy turned to indigenous innovation, its original sectoral system of automobiles was mainly supported by two institutional pillars. The first pillar was strict regulation of entry permission. Through collaboration among the National Development and Reform Commission (NDRC); Ministry of Industry and Information Technology (MIIT); Ministry of Environmental Protection; General Administration of Quality Supervision, Inspection and Quarantine; and other ministries, the government has maintained substantive control over entry into the car-manufacturing sector. The core means is a regulative system based on the "product catalog management," according to which all car products formally launched into the Chinese domestic market for sale must have prior permission from the MIIT to be listed in a regularly updated product catalog. This policy is nominally based on product safety (e.g., collision safety), environmental protection (such as mandatory emission regulations), quality qualification (such as production consistency), and other conditions. Though some critics regard the "catalog-based regulation" a rigid legacy of the planned system, it continues even after the transition to indigenous innovation. At the same time, since the state plays a critical role in resource allocation in China, especially given its influence on the financial sector, local car producers seldom challenge the fundamental regulatory arrangements.

The second pillar was the national strategy of TMFT since the 1980s, which was originally developed to promote the expansion of local industrial capacity. This strategy literally involves the trading of market access for technology with the multinationals possessing advanced technology, as acquisition of intangible IP assets on technologies would be less productive without the benefit of associated operational learning and expertise. So, TMFT in practice encourages JVs between the backbone SOEs and multinationals. The approach began with a JV between Beijing Auto and American Motors Corporation (AMC) in $1984 .{ }^{13}$ Then rapidly, all backbone SOEs, both those managed by the central government (such as First Automobile Work (FAW), Dongfeng Auto, and Shanghai Auto) and those managed by provincial governments (such as Guangzhou Auto, Nanjing Auto, and others), have been included in this wave. By 2000, a total of 71 such automobile-producing JVs had been established, in addition to five other cooperative projects involving multinationals. In order to promote the localization rate of manufacturing, another $557 \mathrm{JVs}$ had been set up to produce components and parts by $1998 .{ }^{14}$ By 2005 , nearly all

\footnotetext{
${ }^{13}$ When the JV was set up, AMC was owned by Renault; later it was acquired by Daimler Chrysler.

${ }^{14}$ Feng, Kaidong (2016) Chinese indigenous innovation in the car sector: being integrated or being the integrator, Chapter 5 of Y. Zhou, W. Lazonick, and Y. Sun (eds.) China as an Innovation Nation, Oxford, UK: Oxford University Press: 133-164
} 
multinationals active in the international market had entered China with carproducing JVs with Chinese SOEs. ${ }^{15}$

\subsection{Through China-Foreign JVs}

As the backbone SOEs focused their strategy on the operation of China-foreign JVs (except in rare cases) ${ }^{16}$ they officially abandoned their own efforts to develop selfowned car brands. ${ }^{17}$ Instead, they stressed production based on imported blueprints with the brands of their foreign JV partners. JV production was often dependent on the introduction of complete sets of equipment, technical licensing, knockdown components, and personnel training from the foreign value network. Before the policy transition to indigenous innovation in 2006, most backbone SOEs had only retained the functions of investment and administration while relying on cooperation with multinationals for product development, manufacturing, and branding.

After the policy transition to indigenous innovation in 2006, backbone SOEs were also required to innovate. However, they did not have sufficient motivation or technical capacity. They had gained great benefits through JV production, while doing indigenous innovation would have created huge risks, without providing a clear prospect of decent returns. Therefore, backbone SOEs generally adopted three strategies during the second half of the 2000s under political pressure and social appeals.

First, they acquired foreign assets. Some multinationals were weakened after the fierce global competition during the 1970s-1990s, which created good conditions for the Chinese to acquire them as a shortcut for gaining technological assets. Not only did the backbone SOEs have such a desire, but so did some new entrants. The well-known case of acquisition of Volvo in 2010 was by the new entrant Geely. However, as the backbone SOEs had not built up their absorptive capacity for assessing and assimilating technologies, they did not perform well in identifying quality assets and negotiating better prices. Beijing Auto bought most of the IPs of SAAB in 2009. However, as revealed by the media afterward, many high-value IPs had already been peeled off before the deal, as previously SAAB had been traded for several rounds on the market. So what Beijing Auto obtained were just two relatively aging platforms, the Saab 9-3 and Saab 9-5, the latest update of which was in the late 1990s.

\footnotetext{
${ }^{15}$ According to the author's rough calculation, there are at least Volkswagen, AMC, Peugeot, Chrysler, Citroen, Nissan, Mitsubishi, GM, Toyota, Honda, Fiat, Ford, GM, etc.

${ }^{16}$ Such as ChangAn Auto. For more details on this exceptional case, see Feng, Kaidong (2016) Chinese indigenous innovation in the car sector: being integrated or being the integrator, Chapter 5 of Y. Zhou, W. Lazonick, and Y. Sun (eds.) China as an Innovation Nation, Oxford, UK: Oxford University Press: 133-164.

${ }^{17}$ FAW was an exception keeping its own car brand, since the brand "Red Flag" has always been regarded as the national car with political symbolism. However, in the 1990s, FAW also gave up the technical platform of Red Flag and replaced it with that of Audi-100 while keeping the Red Flag name.
} 
The Chinese acquisition of Rover was more dramatic. In 2005, two Chinese SOEs, Shanghai Auto and Nanjing Auto, announced acquisition of Rover's core assets. In fact, Rover successfully sold its assets to these two separate buyers, namely, the soft technologies (IP, drawings, etc.) to Shanghai Auto and the hard assets (production equipment and factory buildings) to Nanjing Auto. The chaos about the Rover technologies was not finally resolved until 2007, when Shanghai Auto acquired Nanjing Auto, which allowed it to combine the soft technologies and the hard assets from Rover. Of course, this approach can provide an initial shortcut for backbone SOEs to build their own technological capabilities. However, these firms still need to earn experience through indigenous innovation to become a genuinely competitive car developer for the long term. According to our observations, this has not happened yet.

As a second method to respond to the indigenous innovation drive, backbone SOEs established new brands through their JVs with multinationals. Looking for shortcuts, they often purchased the IPs of some existing or even outdated products (for more affordable cost) from abroad. Adjustments were done on the existing platforms, which were often very marginal, such as redesigning bodywork, installing new auto electronics, improving interiors, etc. However, most products of this nature were less satisfactory to local consumers, who have become picky as they have witnessed superior products entirely developed for them. Many of these selfbuilt brands were soon marginalized on the market, such as the Everus brand launched by the Guangzhou Auto-Honda JV and the Ciimo brand developed by the Dongfeng Auto-Honda JV. Only those really based on localized R\&D were able to survive through tough competition, such as the Baojun brand of the SAIC-GMWuling JV.

The third way was to buy technology from local developers. Some backbone SOEs have come to ally with new local entrants or directly procured technological packages from them. For example, in 2012 Guangzhou Auto signed an agreement with Chery ${ }^{18}$ to obtain the basic technology of the A-class platforms from Chery, as well as the full package for a G3 model. With this agreement, Guangzhou Auto also outsourced the engineering service provided by Chery concerning the engines and the continuously variable transmission gearboxes adopted in the relevant car models. In fact, these inputs aided Guangzhou Auto in developing its own Trumpchi brand.

It is only after 2013, witnessing how the new administration of Xi continues to stress indigenous innovation, that the backbone SOEs have begun to take innovation seriously. Within these firms, the units running self-built brands get promoted in terms of resource support. Baojun, the brand of the Shanghai Auto-GM-Wuling JV, has become a competitive brand in the low-end market. The Trumpchi brand of

\footnotetext{
${ }^{18}$ Chery is one of the leading local firms that focuses on indigenous development of auto products. It was funded by the provincial government of Anhui and entered the car-making sector since 1997. For its distinguished performance in developing indigenous technologies, Chery was considered by the Chinese government as one of the representatives of new local entrants after the policy shift around 2005-2006.
} 
Guangzhou Auto, as mentioned, also made its name in the mid-range market segment. The continual investment in $R \& D$ and relevant experience accumulation after the policy shift have forged their rise. But as newcomers to indigenous innovation, their trajectories of capability growth are not different from those of the forerunning local innovators such as Chery, Geely, BYD, and Great Wall. Longer periods of investment and experience accumulation are needed in order to develop sustainable capability building. All these facts will be clearly demonstrated by our patent analysis later on.

\subsection{Through New Local Entrants}

Since 1997, new local entrants such as Chery and Geely began to produce cars based on different strategies, suggesting the possibility of strategies other than TMFT. ${ }^{19}$ But the entry of these manufacturers was "illegal" to some extent, because they had not been listed in the official catalog yet. These new entrants were mainly supported by local governments. As the spin-off effects of car-making on related industries were attractive, some local governments, in their bid to promote local GDP growth, risked supporting local firms even without official permission from the central regulator. ${ }^{20}$ The support was vital for new entrants, as the local governments not only provided funds but also allowed them to sell their products in local areas. ${ }^{21}$ It is important to note that these new entrants are not the industrial players directly managed by the central government, and represent only local economic power, which is critical for understanding the subsequent policy changes. At least in the car industry, the policy transition from TMFT to the indigenous innovation strategy has not happened in a completely radical manner. This is partly so because the leading cadres of the ministries of industrial administration, especially the MIIT, had often been the former heads of large SOEs. This explains why policy-makers acquiesce in the slow response of backbone SOEs to this strategic transition, especially in their continued emphasis on JV production.

The influx of new local entrants has fundamentally changed the rules of the game in China's car industry. They offer more cost-effective products and are more inclined to listen to the needs of local consumers by continually launching new products, which makes Sino-foreign JVs unable to sustain high profits by producing a handful of outdated models. Thus, since 2001, as the new entrants gradually obtained regulatory approval, the entire production scale and the amounts of new

\footnotetext{
${ }^{19} \mathrm{Lu}$, Feng and Kaidong Feng (2005) The Policy to Develop the Indigenous Automobile Industry (Fazhan Woguo Zizhu Zhishi Chanquan Qiche Gongye de Zhengce Xuanze). Beijing: Peking University Press

${ }^{20}$ Thun, Eric (2006) Changing Lanes in China: Foreign Direct Investment, Local Governments, and Auto Sector Development. Cambridge: Cambridge University Press

${ }^{21}$ See Chapter 3 in Lu, Feng and Kaidong Feng (2005) The Policy to Develop the Indigenous Automobile Industry (in Chinese). Beijing: Peking University Press, pp. 42-74
} 


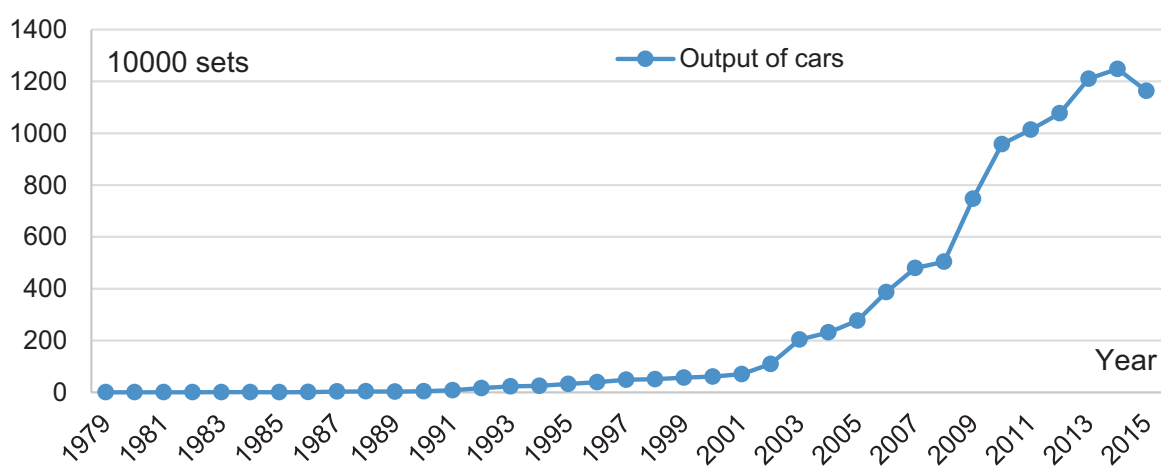

Fig. 1 Output of Chinese car sector. (Source: China Automotive Industry Yearbooks)

products launched annually in China's car industry have skyrocketed, due to the leveraging effects created by new firms (see Fig. 1).

As new local entrants often lack technology accumulation, their first-generation products were developed mainly by mimicking existing products. Thus, after 2001, when their threat to incumbents was recognized, multinationals sued China's new local car-makers for IP violation in a series of cases. These disputes affected public opinion and reinforced the notion that new local entrants were technologically backward.

Therefore, the new entrants who survived the initial phase of market competition demonstrated obvious commitment to developing self-owned technologies to solve their sustainability problems. Their efforts, though diverse, can be categorized into three types. Firstly, they invested heavily in in-house R\&D. Chery, for example, was founded in 1997, and by 2005 it had an R\&D center of more than 2000 professionals. In addition to the development of car models, Chery also has specialized in engines, gearboxes, new materials, electronic control systems, and so on. The cultivation of this R\&D force was supported by high resource density: in 2005, on average, each of Chery's R\&D personnel was involved in more than 12 projects at the same time. By 2012, Chery's R\&D team reached its peak, with more than 6000 people and more than 120 ongoing projects for developing car models and important assemblies. ${ }^{22}$

The second type of activity that the surviving new entrants undertook was to establish their own core supply system to provide key technical modules, such as air-conditioning, automotive electronics, stamping molds, and so on. At the beginning, they had to rely on existing local suppliers. However, under TMFT, most car component suppliers, though not all, were attached to a Sino-foreign JV value network. As those incumbents, especially the multinational part, had tight control over core suppliers, i.e., the tier-1 suppliers, the new entrants could only reach tier- 2 or even more marginal suppliers. However, the technologically inferior tier-2

\footnotetext{
${ }^{22}$ The data are collected by one of the authors through his annual on-site investigations and interviews at Chery during 2003-2012.
} 
suppliers $^{23}$ were not willing to provide engineering R\&D services to new enterprises, to avoid potential pressure from their car-making partners. All these constrained the scope and quality of components the new entrants could outsource. ${ }^{24}$ To break through the roof, the new entrants had to set up their own tier-1 core supplier system. The concrete approach was to invest in cooperation with talented engineers who have already accumulated considerable experience through their prior work at giant international firms. For these engineers, the plans of Chery and Geely offered them a chance to start their own businesses. After witnessing their rapid growth, some established suppliers gradually became willing to set up JVs or specialized factories for these new players. Chery, for example, by 2012, had established a network of more than 200 tier-1 suppliers and already had several tier-1 suppliers to choose from in some areas. These achievements enable the new entrants to independently develop and produce cars and key modules, including a large number of patented technologies.

The third type of activity that the surviving new entrants underwent was a wide range of technical cooperation with international professional technology firms. After the 1990s, the growth of the global mainstream market had slowed, and some professional engineering technology providers began to develop strong incentives to open up the Chinese market, giving the new entrants opportunities to outsource engineering services and learn through cooperation with these service providers. As the earliest case of this kind, the Italy-based design house, Pininfarina, in 1991, took the initiative to approach Hafei Auto (a Chinese minibus manufacturer) to inquire into whether the latter was willing to employ its services. ${ }^{25}$ This pattern quickly spread among local newcomers, who sought specialized services on the global market in different fields, such as systemic configuration, chassis engineering, engine calibration, and so on.

These kinds of cooperation were not just simple turn-key projects, but involved personnel training. Young and most elite Chinese engineers participated in these

\footnotetext{
${ }^{23}$ The terms "tier-1" and "tier-2" are defined by the closeness of suppliers to the flagship firms (car producers) in their value chains. When a project for developing new products is started by a flagship firm, its tier-1 suppliers are required to set up corresponding development projects in a parallel manner and send their representatives to join the development team of flagship firms. By doing so, the development activities both internally in the flagship firms and in each tier-1 supplier are integrated to serve the purpose of developing a product. Therefore, the tier-1 suppliers are obliged to develop their in-house technological capability and have close collaboration with the flagship firms in the long run. By contrast, the tier-2 suppliers are not included for participating in core activities of development immediately. Rather, they are expected to be the capacity buffer or to provide more options for the flagship firms when a product design has been solidified. Therefore, in most cases, the technological capabilities of tier-2 suppliers are incomparable to those of tier-1 suppliers. For the collaboration between flagship firms and their tier-1 suppliers, see Clark, Kim B., and Takahiro Fujimoto (1991) Product Development Performance: Strategy, Organization, and Management in the World Automobile Industry. Boston, MA: Harvard Business School Press.

${ }^{24}$ This also explains to some extent why the early products of new businesses are being criticized in the same way that multinationals produce vehicles through joint ventures.

${ }^{25} \mathrm{Lu}$, Feng and Kaidong Feng (2005) The Policy to Develop the Indigenous Automobile Industry (in Chinese). Beijing: Peking University Press, p. 45
} 
Table 1 Newly launched car models in the Chinese market

\begin{tabular}{l|l|l|l|l|l|l|l|l|l}
\hline Year & 2001 & 2002 & 2003 & 2004 & 2005 & 2006 & 2007 & 2008 & 2009 \\
\hline $\begin{array}{l}\text { New } \\
\text { models }\end{array}$ & 13 & 28 & 50 & $50-$ & $80+$ & 117 & 90 & 107 & 221 \\
\hline
\end{tabular}

Source: Feng (2016), p. 151)

projects. The foreign partners had to cooperate in such learning schemes to win a long-term place in the emerging Chinese car market. ${ }^{26}$ In such schemes, the Chinese participants played a more dominant role in cooperation, which helped them better identify technologies at the systemic level and explore more frontier issues. ${ }^{27}$

New local entrants kept their focus on technological progress for sustainable survival, which also changed the behaviors of multinationals. Before they were challenged by new local entrants, multinationals rarely launched new products on the Chinese market, despite the fact that a large number of multinationals had actually established their Sino-foreign JVs before 2001. In 2001, there were only 13 new car models in China by 12 vehicle-producing JVs set up by international giants (see Table 1). Only after the new local entrants were allowed to enter the industry was product-based competition triggered. After that, the rules of the game have changed, and the amount of new products on the market every year has increased rapidly, above 100 for most of the years after 2006, many with investment by multinationals.

\section{China's Technological Innovation in EV Industry}

\subsection{Government-Backed Development}

\subsubsection{Central Government}

The technological progress in the Chinese EV sector presents a series of characteristics dissimilar to the FFV sector. The discontinuity of automotive technological progress, created by the rise of $\mathrm{EV}$, is perceived as an opportunity for latecomers to overtake their competitors. The Chinese government has provided long-term and consistent support for indigenous innovation in this domain. This measure

\footnotetext{
${ }^{26} \mathrm{It}$ is important to note that developing new models is an expensive investment activity, so in the original international market, the opportunity to participate in new model development projects is highly valuable and limited; only these new enterprises from China are extravagantly spending efforts to save money from other areas to start one after another. The new model project has become a new opportunity that technology service companies cannot give up. Even if Chinese companies are more concerned about learning technology from them, they are still passively accepting this. In fact, they have also gained great benefits from the development of the Chinese auto industry. After the growth of new Chinese companies, these international technology companies continue to obtain cooperation contracts, although their cooperation is no longer clearly "teacher-student" relations, so they have successfully nurtured a new group of consumers.

${ }^{27}$ Feng, Kaidong, Tongyao Yin, and Yanmin Wang (2007) Innovation pattern of Chery (Qirui de Chuangxin Moshi). China Soft Science. No.3: 76-84
} 
incentivizes local actors to innovate and helps to shape an active ecology where developers of relevant technologies, such as the mobile Internet, big data, and AI, take it as a good chance to extend their business to the automobile industry. Under such circumstances, not only new local entrants but also some backbone SOEs have better performance in EVs than in FFVs.

The Chinese government began to aid EV development projects in 1992. At that time policies were initiated to address the concern of "(petroleum) energy consumption." The Ministry of Science and Technology (MOST) was the first at the central government level to act on the EV issue. As MOST was not set up for economic planning or industrial administration, it paid more attention to technological advances and did not strictly follow the TMFT strategy. Furthermore, it emphasized indigenous innovation when subsidizing EV development. Later, NDRC and MIIT took part in the support of EV after the 2006 policy shift and treated the advent of EVs as an opportunity to implement a leapfrogging strategy. NDRC and MIIT have gradually become the ministries steering EV policies, as they command more resources and administrative power.

However, the ministries were not directly involved in commercial competition, could not perceive potential targets still under water, and were not sensitive to various commercial considerations and technological choices. What they could identify as targets for leapfrogging strategy were technologies already on the market and advocated by international giants. Then they set metrics for the measurement of technical objectives for a given period of time, which was typical of "technological mounting" programs, namely, to mobilize domestic actors to achieve breakthroughs. ${ }^{28}$ In the special program for EV under the National Technology Research and Development Program (the "863 Program"), ${ }^{29}$ which is part of the 10th FiveYear Plan, planners from the central government emphasized fuel cell vehicles, traditional non-plug-in hybrid EVs (HEV), and pure electrical vehicles (PEV) as the three selected technologies that government supported since 2001. Among them, the HEV and fuel cell vehicles had long been advocated by Japanese car-makers. However, due to the lack of the battery technologies for PEV, people still had their eyes fixed on traditional lead-acid and Ni-MH batteries. Lithium batteries, which were later proven to be a better choice, had not been included for policy consideration at that time due to cost and safety issues.

The government is also a critical player in shaping the technological trajectory of the rise of Chinese EVs. To circumvent the advantages of international giants, such as that of Toyota in HEVs, the Chinese government released policies such as the

\footnotetext{
${ }^{28}$ Technological mounting program was a traditional pattern for Chinese central planners to facilitate technological progress. In such kind of programs, ministries would mobilize all the major units in relevant domains, including those of universities, research institutes, factories, and so on. Collaboration between these units would be arranged by the ministries with great details, so would the tasks of technological progress for each participant.

${ }^{29}$ The "863 Program" is a national program for basic research. It is led by the Chinese central government and focuses on a series of selected areas only. This program is named after its starting date, namely, March (the third month) of 1986. It is always regarded as a signpost for the governmental emphasis on research.
} 
"Administrative Regulations on New Energy Vehicle Production Enterprises and Product Access" in 2017 to clearly exclude the HEV from the officially defined "new energy vehicles" in China. Therefore, only the PEV, plug-in hybrid EV (PHEV), and fuel cell vehicle development can receive governmental incentives and other special treatments, leading local Chinese firms to spend more on PEV and PHEV.

\subsubsection{Local Governments}

In addition to the catching-up strategy of the central government, the rise of EV also benefited from the policy actions of provincial governments. The "image creation" campaign by provinces and cities provides a rising market for EV. Nowadays demonstration of commercial operation of EV has become an important element of large international events and exhibitions organized by Chinese cities. For example, the first Chinese EV demonstration was at the Beijing 2008 Olympic Game. Shenzhen hosted the 26th Summer Universiade in 2011, which became the start for a new round of EV demonstration by BYD. The municipal government of Shenzhen launched a project to sponsor the public transportation service to purchase 200 electric buses (BYD and another EV coach producer together were awarded the dominant share) and also invested in an EV taxi company, purchasing 500 BYD PEVs. This was the first large-scale commercial operation of EVs in China. As these projects became very successful, the Shenzhen government decided that all newly added public buses must be electrically driven, as well as all newly licensed taxis after 2014. These experiences were partly copied by the government of Beijing in 2014 (for the APEC conference) and Hangzhou in 2016 (for the G20 Summit).

Meanwhile, the central government also propelled the competition among regional governments for EV development. Regional governments have to compete against each other. In 2009, a "thousand EVs in each of ten cities" program was launched, and 13 cities were listed as pilots to promote EV application. In 2010 and 2011, another seven and five cities were included, respectively. In 2012 a broadened program, namely, the "New Energy Automotive Industry Development Plan (20122020)," was announced with a nationwide target of production and sales of over 500,000 new energy vehicles by $2015 .^{30}$ To implement these programs, the central government subsidizes EV purchasers and has ordered regional governments to follow its incentive plan. The sum of subsidies provided by central and regional governments usually reaches $50 \%$ of the purchase price. These policies create a series of consequences. Customers become more willing to buy; more particularly, regional governments are incentivized to provide subsidies to benefit the local economy. For example, Hangzhou's government has sponsored the rise of two EV manufacturers, Kandi and Zotye. ${ }^{31}$ Beijing's municipal government incentivized and pressured Beijing Auto to start a subsidiary on PEV production.

\footnotetext{
${ }^{30}$ Shen, Qunhong, Kaidong Feng, and Xiaobo Zhang (2016) Divergent technological strategies among leading electric vehicle firms in China: Multiplicity of institutional logics and responses of firms. Science \& Public Policy 43.4:scv056

${ }^{31}$ Kandi is a privately owned industrial group, established in 2002, focused on manufacturing compact cars. In 2013, Kandi and Geely jointly (50\%-50\%) invested in an EV producer, Kandi
} 
Beijing Auto, JAC (an SOE owned by Anhui Province), and ChangAn Auto (an SOE originating from the state-owned weapon-making enterprise) are the firstmovers among SOEs to take EV as an important business and a platform to rebuild their technical capabilities.

\subsection{Chery-Led Development}

The MOST encouraged local firms to participate in projects it commissioned and funded. Backbone SOEs, such as FAW and Dongfeng Auto, ${ }^{32}$ were those that the the MOST needed to persuade to join in. However, some new entrants signed up for these programs and also invested their own money. A typical example is Chery, which took part in the $863 \mathrm{EV}$ program in 2001 and infused its strategic resources into it. ${ }^{33}$ Therefore, in the second half of the $863 \mathrm{EV}$ program, which started in 2003 , Chery has become the most important participant, and its automotive engineering institute was accredited by the MOST as "national engineering and technology center for energy-saving and environment-protection vehicles."

During this phase, Chery invested heavily in HEV, partly out of its eagerness to be recognized by the central government as a competent car-maker. It even invested in a series of collaborative developmental projects with Ricardo, a renowned British technological firm, starting in 2004. With intensive learning through a 4-year period, Chery mastered various mainstream HEV technologies, including a range of light, medium and full modes of electric motor-engine hybridization.

However, Chery's technological choice was problematic. As the development proceeded, Chinese developers found that Japanese manufacturers, particularly Toyota, have obvious first-mover advantage in this area. Leading Japanese firms had already patented a large number of high-value inventions, and many of these patented technologies were fundamental to this domain and difficult for latecomers to circumvent. Therefore, not only Chery but also giant firms from Europe and North America were hardly able to proceed with commercialization of their technologies. Technological ecology in the fuel cell EV was also similar, and some core patents were in the hands of a limited number of international giant firms.

EV. Zotye is also a private industrial group, established in 2003. It started to produce cars in 2003 and entered the EV market in 2009.

${ }^{32} \mathrm{FAW}$ is the most privileged automobile producer in China. It was the first automobile works established in China in 1953 and had been always the largest Chinese automobile producer before 2005 (when overtaken by Shanghai Auto). Dongfeng Auto is also a leading backbone SOE established in 1969. As Dongfeng Auto was the second largest automobile group directly constructed under the instruction of the State Council, common Chinese also refer to it as "Second Automobile Works." This name also indicates the significance of Dongfeng Auto in China's automobile industry.

${ }^{33}$ MOST provided Chery only 0.5 million RMB in the first half of the project during 2001-2003. As a reference, Chery imported a Toyota Prius (the first mass-produced hybrid car worldwide) from abroad, which cost 0.8 million RMB. 


\subsection{The BYD-Led Development}

The rise of BYD in EV is a story highly similar to that of the new entrants' rise in the FFV sector. BYD was originally below the radars of the government and traditional Chinese automotive community. BYD had built strong capacity in battery development by the early 2000s and became globally competitive in providing lithium and Ni-MH batteries for laptops and cell phones.

In 2005, a research team at MIT released their findings about lithium iron phosphate as the cathode material for batteries. BYD reacted quickly, launched its industrialization program in 2006, and started to produce large volumes of lithium iron batteries in 2009. The reason for BYD's efficient reaction lies not only in its longterm accumulation in battery technology but also in its research-oriented core organization. BYD was created by a group of former scientists of China's General Research Institute for Nonferrous Metals and maintained the tradition of carrying out wide-ranging developmental activities in-house, from researching metal materials to producing battery packaging and developing cars. After BYD successfully launched its EV models named F3DM and Qin, most of the EV manufacturers in China turned to PEV or PHEV. Chinese developers created a niche market and gave up their previous mistaken trajectory, the HEV.

\subsection{Overall Assessment}

China's EV industry outpaced the USA's to become the world's No.1 in 2015 and accelerated the technological development in China. Relevant suppliers of components and engineering service have been quickly established, including batteries, charging facilities, electrical and electronic control, etc. Taking the battery as an example, in addition to BYD, there are more than ten large-scale battery providers in China, including CATL, Fortunate Solar, Guoxuan High-Tech, Optimum Nano, and LiShen. ${ }^{34}$

New local entrants are the major drivers to China's EV rise, including BYD, Chery, Zotye, Geely (in cooperation with the Kandi Group), and Great Wall. ${ }^{35}$ Attacking the previous industrial ecology, they actively embraced the disruptive change of technology to gain greater market share and greater government recognition.

\footnotetext{
${ }^{34}$ All the firms listed here are newly established private firms.

${ }^{35} \mathrm{Geely}$ is a private firm and a leading one among the new local firms. It entered the automobile industry in

1997, focusing on compact cars and a low-price strategy during its early phase. For the EV business, Geely mainly relies on collaboration with the Kandi Group, as these two jointly invest in Kandi EV. Great Wall is also a privately run company with partial governmental ownership. It entered the automobile industry in 1996 and is well known for its SUVs.
} 


\section{$4 \quad$ Patent Analysis in China's Car-Making Industry}

As mentioned previously, key technologies for car-making can be tacit and often embedded in complex technological or social networks. Therefore, for car-makers and technological inventors, patenting is just one of the several methods to extract economic benefits from innovations. ${ }^{36,37}$ Even international giant firms may have reservations regarding how much to spend on patenting. ${ }^{38}$ Thus, it appears that patent analysis may not be highly reliable for assessing the definite values of automotive technologies. Nevertheless, a comprehensive patent analysis is expected to be enlightening in this study. First of all, it can indicate the behavioral evolution of a select group of firms and the comparative tendencies among different groups. Secondly, the gaps in patenting strengths among different car-makers or groups in China are substantial rather than nominal; thus, analyzing patents becomes an effective method to demonstrate the capability gaps.

This section mainly analyzes the patent applications of 25 selected firms documented by China's State Intellectual Property Office (SIPO). According to the China Automotive Industry Yearbook (2016), the 25 firms are directly related to the top 12 Chinese car-makers, including multinationals, SOEs, and new entrants, with each producing more than 400,000 vehicles in 2015 (see Appendix 1). In the following, we categorize them into three groups, the multinationals, the backbone SOEs and their JVs with foreign partners, and the new local entrants.

\subsection{General Patent Analysis}

In China, patents are divided into three categories: inventions, utility models, and appearance designs. Among these, the invention patent requires the highest novelty and undergoes a more rigorous examination procedure, which gives it longer protection and higher value. Therefore, the patent portfolio of a firm can partly indicate its technical orientation. In the car-making industry, from 1999 to 2017, multinationals have submitted a total number of 87,089 patent applications in China, while new local entrants filed 66,043 and backbone SOEs and JVs filed 32,227. As for portfolios in the three categories of patent, multinationals have the highest ratio of inventions, at $79.53 \%(69,265)$, and a low ratio of utility models, merely $3.06 \%$. The respective ratios for new local entrants are $32.84 \%$ and $50.24 \%$, and for backbone SOEs and JVs $20.55 \%$ and $57.72 \%$ (see Fig. 2). The group of backbone SOEs and

\footnotetext{
${ }^{36}$ Levin, Richard C., Alvin K. Klevorick, Richard R. Nelson, and Sidney G. Winter (1987) Appropriating the returns from industrial research and development." Brookings Papers on Economic Activity, No. 3: 783-820

${ }^{37}$ Nelson, Richard (1990) Capitalism as an engine of progress. Research Policy 19(3): 193-214 ${ }^{38}$ For example, it is well recognized within the automotive community that given the same conditions of technology, Japanese firms, especially Toyota and Honda, are obviously keener on patenting.
} 


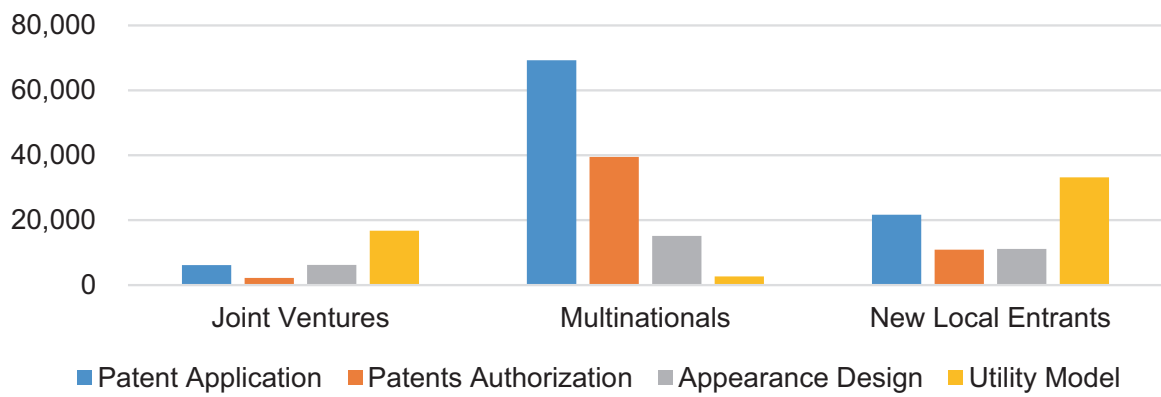

Fig. 2 Patenting activities of firms from three groups, 1999-2017. (Note: collected through incoPat)

JVs exhibits obvious weakness in patent applications, as $58 \%$ of their patents fall in the category of utility model (Yang and Mu 2009).

The patent grant rate is another index to look into. According to the report released by National Intellectual Property Administration in 2016, the rate for the JVs is just $35.35 \%$, markedly below that of multinationals and new local entrants, which are $57.01 \%$ and $50.28 \%$ respectively.

Multinationals are the first-movers at implementing patenting strategy in China, accounting for the absolute majority of patents in automobiles prior to 2004 in China. However, due to the absence of strong rivalry in China, the patent portfolios of multinationals remained thin early on. Only after being challenged by new local entrants did their quantity of patent applications in China rise quickly after 2005. Toyota, GM, Honda, Hyundai, and Ford are the top five applicants for Chinese carmaking invention patents, accounting for $56.3 \%$ in total among the 25 selected firms. Most patent applications of multinationals are submitted by entities from their home countries, which indicate that their collaboration with their JV partners in China remains highly irrelevant to their patent applications. For example, among the 16,708 patents applied for Toyota in China, there are only 5 patents with Chinese co-applicants. Toyota subsidiaries in China, including the Toyota (China) Research Center, FAW-Toyota R\&D Center, and Guangzhou Auto-Toyota R\&D Center, have only submitted 19 invention patent applications in the past 40 years. That is to say, the offshore R\&D may have helped the multinationals to localize their technological capability to better fit the local market or forward local customers' feedback to their global headquarters to enhance R\&D performance. ${ }^{39}$ Anyhow, it indicates that multinationals such as Toyota do not allow their subsidiaries in China to cultivate real technological capability.

In 2003, GM claimed that the QQ model, a minicar product of Chery, violated its IP of the Matiz model, which was originally developed by Daewoo. In response to the lawsuit, Chery urgently submitted more than 20 patent applications to SIPO,

\footnotetext{
${ }^{39}$ Liu, Mengchun, and ShinHorng Chen (2012) “MNCs' offshore R\&D networks in host country's regional innovation system: The case of Taiwan-based firms in China." Research Policy, 41(6): $1107-1120$
} 


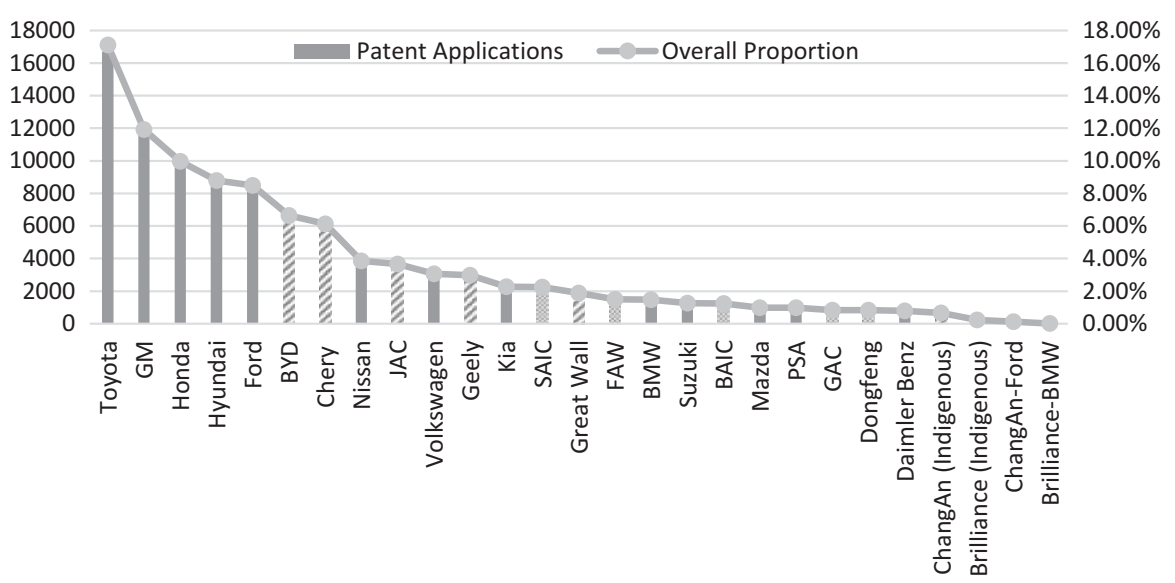

Fig. 3 Patent applications and overall proportion in Automotive, 1999-2017. (Note: Numbers of patent applications in China during 1999-2017, in the field of Automotive, collected from National Intellectual Property Administration, China.)

which could be considered the point at which local car-makers began to emphasize patenting. After that, we have witnessed the rise of new local entrants, which gradually become the second largest group of patent applicants, only after the multinationals. In 2016, the number of invention patent applications submitted by seven Chinese new local entrants has reached 3386, equivalent to a half of that submitted by the 13 multinationals. The leading group of new local firms, namely, BYD, Chery, Geely, and Great Wall, even exceed some multinationals, such as Volkswagen, Kia, and BMW, in patent applications (see Fig. 3).

We are not arguing that the technological expertise of these Chinese firms has already overtaken that of multinationals. However, at least data indicate a shift in their IP strategies in the Chinese market. In fact, the total number of invention patent applications submitted by the new local entrants has already surpassed the sum submitted by Toyota and Honda after 2012. This is remarkable, as the leading Japanese firms are always very active in patent applications. The growth rate of invention patent applications filed by the new local entrants as a whole is almost equal to that of the multinationals. As for Sino-foreign JVs, although the sum of their patent applications has also increased after 2010, the growth rate is still significantly behind that of the multinationals and the new local entrants.

\subsection{Patents in FFV Sector: Engines As an Example}

Multinationals started their patenting in China much earlier with much better performance. Over the past 20 years, multinationals have already submitted at least 7695 applications on engine technologies, and this has grown steadily, from less than 100 applications in 2003 to above 600 every year after 2011. US and 


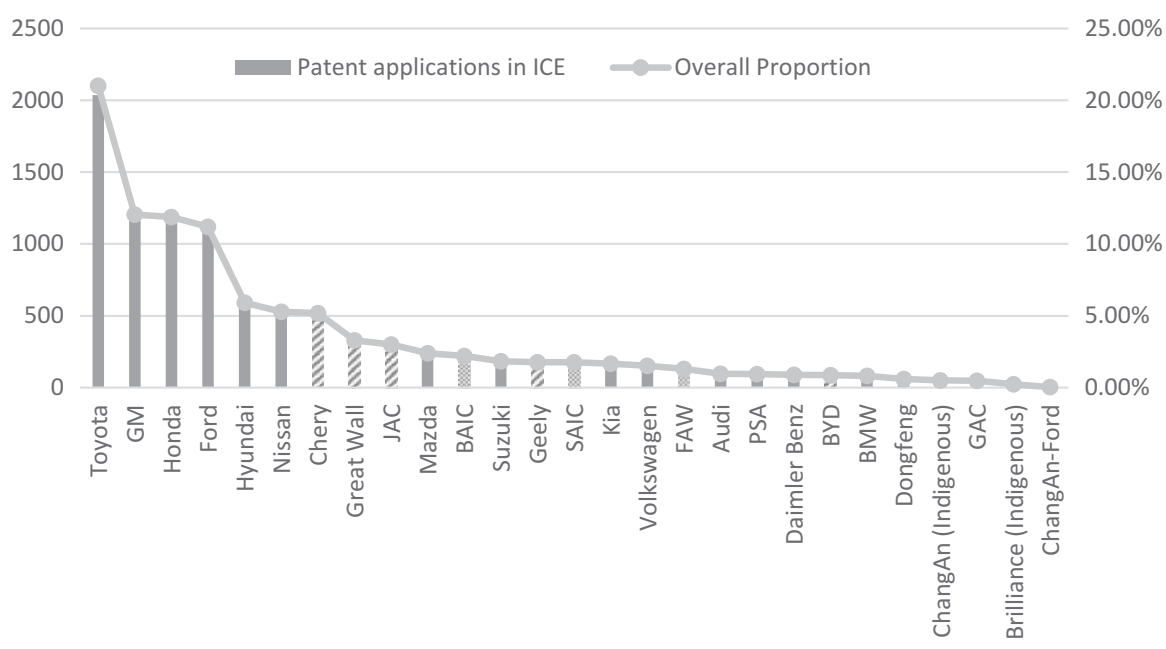

Fig. 4 Patent applications and overall proportion in ICE, 1999-2017. (Note: Numbers of patent applications in China during 1999-2017, in the field of ICE, collected from National Intellectual Property Administration, China.)

Japanese car manufacturers have striking advantages in this field, as Toyota has accumulated 2285 applications on engines, GM 1167, Ford 1084, and Honda 1049 (see Fig. 4). In recent years, although people are arguing about the American deindustrialization or the decline of Detroit's automotive industry, the American car-makers still maintain a higher innovation rate on engines than their overall general level through strengthening specialized R\&D and utilizing links with European and Japanese collaborators. ${ }^{40}$ Gradually, Japanese and Korean actors have already transferred their focus to the EV technologies rather than the ICE. For example, the invention patent applications of Honda for engine technologies in 2016 have declined by more than $50 \%$ from 10 years ago.

Compared with the leading group of multinationals, the new local entrants and backbone SOEs with their Sino-foreign JVs exhibit obvious disadvantages in engine technologies, with a total of only 1434 and 704 cumulative invention patents, respectively. Before 2002, only some backbone SOEs had the competence to patent engine technologies. However, the number of their applications was very limited, just one or two a year. Only with the rise of the new entrants did local applications in engine patents start to increase. For example, Chery's invention application started to top the local Chinese applicants in 2005, with about 40 annual applications on average.

In general, the patenting performance of new local entrants is far better than the backbone SOEs and their JVs with multinationals. Among the backbone SOEs,

\footnotetext{
${ }^{40}$ Hannigan, Thomas J., Marcelo Cano-Kollmann, and Ram Mudambi (2015) Thriving innovation amidst manufacturing decline: the Detroit auto cluster and the resilience of local knowledge production. Industrial and Corporate Change, 24(3): 613-634
} 
Shanghai Auto has the best performing Sino-foreign JV, Shanghai Auto-GM. However, Shanghai Auto and its JVs have only 208 invention patent applications, clearly not comparable to the leading new entrants such as Chery or Great Wall. Out of the 208 applications, only 38 are co-submitted with its multinational partners, which again indicates the inefficiency of technological learning under the TMFT scheme.

\subsection{Patents in EV Sector}

Compared with the FFVs, the power of EVs mainly depends on new energy supplies such as batteries or fuel cells, which leads to remarkable changes in core modules and the overall design. The huge potential of the Chinese EV market has attracted multinationals to apply for patents in China. Thanks to the governmental incentive programs, local applicants have made rapid growth in EV patenting. ${ }^{41,42}$ Prima facie, the group of multinationals still has an absolute advantage with over 16,758 invention applications compared to 938 from backbone SOEs and JVs and 4303 from new local entrants. Yet a closer look shows that among those multinationals, 6316 applications are submitted by Toyota alone. The gap between local Chinese applicants and multinationals is not as formidable as in the ICE sector. Especially BYD, together with GM, having 2188 and 2537 invention patent applications, respectively, has become the second-tier applicants, with visible advantages over the third-tier applicants, including Hyundai, Ford, Nissan, Honda, and Chery. Even a handful of backbone SOEs, such as Beijing Auto, Shanghai Auto, and ChangAn Auto, are incentivized by governmental policies to develop their own technologies and file for patents (see Fig. 5).

BYD, as the largest EV producer in China today, cooperates with DaimlerBenz in a JV, namely, the Denza, to produce PEV. BYD and Daimler-Benz collaborate on the bodywork design. And BYD leads most of the rest product development tasks in Denza. Indeed, the technological capability of BYD in EV, embodied in 2188 invention patent applications, is the reason why DaimlerBenz chose to collaborate with the young Chinese car-maker. ${ }^{43}$

In fact, only Toyota and GM can maintain their leading positions ahead of BYD, although the advantages of GM have begun to fade. Further, given that Toyota has long been more focused on HEV rather than PEV or PHEV, which are the domains that BYD stresses, more detailed analyses need to be done in the future to judge the leadership contest in each market segment.

\footnotetext{
${ }^{41}$ Zheng, Jie, Shomik Mehndiratta, Jessica Y. Guo, and Zhi Liu (2012) Strategic policies and demonstration program of electric vehicle in China. Transport Policy, 19(1): 17-25

${ }^{42}$ Yang, Lifeng, Jinhua Xu, and Peter Neuhäusler (2013) Electric vehicle technology in China: an exploratory patent analysis. World Patent Information, 35(4): 305-312

${ }^{43}$ Up to 2015, Daimler-Benz has only applied for 139 invention patents in China.
} 


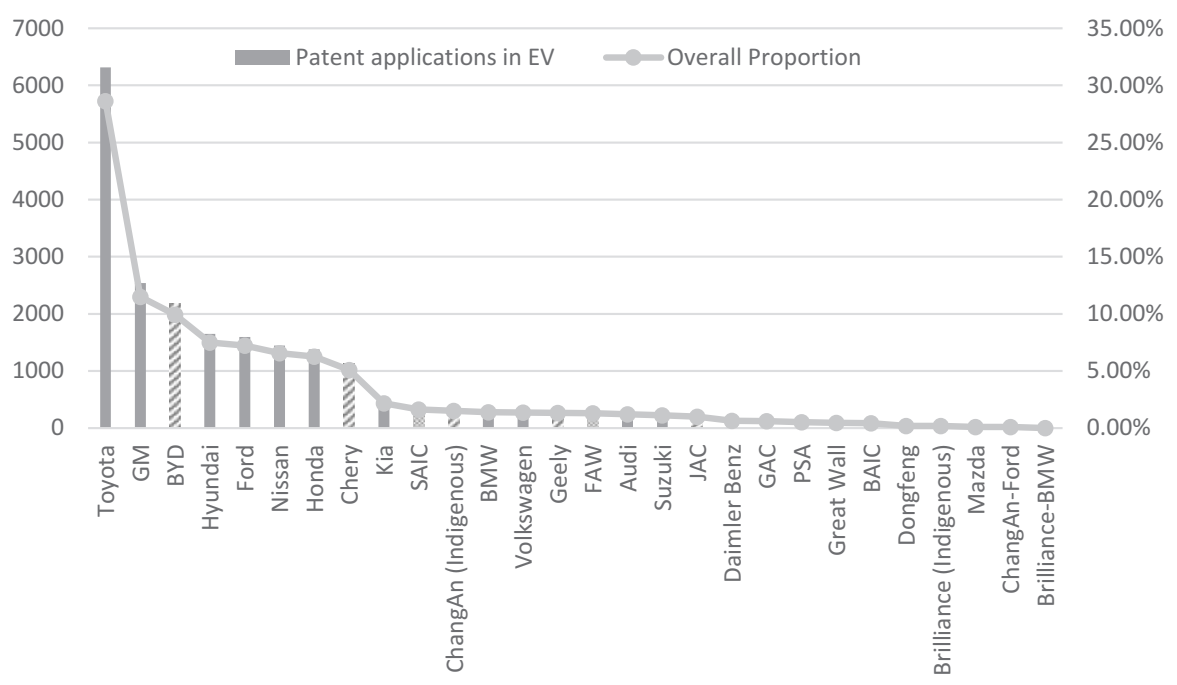

Fig. 5 Patent applications and overall proportion in EV, 1999-2017. (Note: Numbers of patent applications in China during 1999-2017, in the field of EV, collected from National Intellectual Property Administration, China.)

\section{$5 \quad$ Conclusion and Prospects}

The Chinese policy transition to indigenous innovation during 2005-2006 is a clear milestone for understanding the technological progress in this country. In the carmaking industry, two rounds of invasion by newcomers, from the periphery to the central stage, are critical. The first round, represented by the entries of Chery, Geely, and so on, built the foundation for the policy shift. The second round was led by BYD, with a new mindset of developing EV. Overall, it is the new local entrants that have been steering China's automotive industry efforts to catch up in automotive technologies, while backbone SOEs have lagged behind as they have been shackled by their own previous policy practices. Guellec and van Pottelsberghe point out that the higher the ratio of indigenous innovation is, the easier it is for developing countries to free themselves from their reliance on foreign technologies. Our comparative patent analysis between the new local entrants and the backbone SOEs has also amply demonstrated this. ${ }^{44}$

The governmental support has provided a favorable environment for Chinese indigenous innovations, especially those in the EV sector. On the prospects for sustainable development in the long run, policy-makers in China have decided to shift the policies again, in order to create a more competition-oriented industry. As a

\footnotetext{
${ }^{44}$ Guellec, Dominique, and Bruno van Pottelsberghe de la Potterie (2001) The internationalisation of technology-analysed with patent data. Research Policy, 30(8): 1253-1266
} 
result, the restrictions on foreign investment in China's EV industry have been removed in 2018; fully liberalized entry into the entire auto industry will be allowed in 5 years; the subsidy for purchasing EV will be totally abolished by 2020 and has already been gradually reduced since 2017 . In addition, the long-existing JVs will lose all policy preferences that they have enjoyed, the backbone SOEs will not have the same attractiveness to multinationals anymore, and all EV producers need to enhance the cost performance of their products in order to compete against the FFVs. In short, there will be a reshuffling in the Chinese car-making industry, which can be another big opportunity for the new local entrants, as they have the most experience necessary to survive unfavorable institutional circumstances and tough competition.

\section{Appendix 1: Firms in Different Categories (25 Firms Analyzed in This Chapter)}

\begin{tabular}{l}
\hline Multinationals \\
$\begin{array}{l}\text { Toyota, Honda, General Motor, Ford, Hyundai, Nissan, Kia, BMW, Volkswagen (and Audi), } \\
\text { Suzuki, Daimler-Benz, Mazda, PSA Peugeot Citroen }\end{array}$ \\
\hline Backbone SOEs with Sino-Foreign JVs \\
\hline $\begin{array}{l}\text { FAW, Shanghai Auto (SAIC), Dongfeng Auto, Beijing Auto (BAIC), Guangzhou Auto } \\
\text { (GAIC), ChangAn Auto (JV), Brilliance Auto (JV) }\end{array}$ \\
\hline New Local Entrants \\
\hline $\begin{array}{l}\text { BYD, Geely, Chery, JAC, Great Wall, ChangAn Auto (indigenous), Brilliance Auto } \\
\text { (indigenous) }\end{array}$
\end{tabular}

\section{References}

Anderson, P., \& Tushman, M. L. (1990). Technological discontinuities and dominant designs: A cyclical model of technological change. Administrative Science Quarterly, 35, 604-633.

Clark, K. B. (1985). The interaction of design hierarchies and market concepts in technological evolution. Research Policy, 14(5), 235-251.

Clark, K. B., \& Fujimoto, T. (1991). Product development performance: Strategy, organization, and management in the world automobile industry. Boston: Harvard Business School Press.

Drucker, P. F. (1946). Concept of the corporation. New York: John Day.

Feng, K. (2016). Chapter 5: Chinese indigenous innovation in the car sector: Being integrated or being the integrator. In Y. Zhou, W. Lazonick, \& Y. Sun (Eds.), China as an innovation nation (pp. 133-164). Oxford: Oxford University Press.

Feng, K. T. Y., \& Wang, Y. (2007). Innovation pattern of Chery (Qirui de Chuangxin Moshi). China Soft Science, (3), 76-84.

Guellec, D., \& van Pottelsberghe de la Potterie, B. (2001). The internationalisation of technology analysed with patent data. Research Policy, 30(8), 1253-1266.

Hannigan, T. J., Cano-Kollmann, M., \& Mudambi, R. (2015). Thriving innovation amidst manufacturing decline: The Detroit auto cluster and the resilience of local knowledge production. Industrial and Corporate Change, 24(3), 613-634. 
Kim, L. (1997). Imitation to Innovation: The dynamics of Korea's technological learning. Boston: Harvard Business School Press.

Levin, R. C., Klevorich, A. K., Nelson, R. R., \& Winter, S. G. (1987). Appropriating the returns from industrial research and development. Brookings Papers on Economic Activity, 18(3), 783-820.

Liu, M., \& Chen, S. H. (2012). MNCs' offshore R\&D networks in host country's regional innovation system: The case of Taiwan-based firms in China. Research Policy, 41(6), 1107-1120.

Lu, F., \& Feng, K. (2005). The policy to develop the indigenous automobile industry (Fazhan Woguo Zizhu Zhishi Chanquan Qiche Gongye de Zhengce Xuanze). Beijing: Peking University Press.

Nelson, R. (1990). Capitalism as an engine of progress. Research Policy, 19(3), 193-214.

Pavitt, K. (1984). Sectoral patterns of technical change: Towards a taxonomy and a theory. Research Policy, 13(6), 343-374.

Perez, C., \& Soete, L. (1988). Catching up in technology: Entry barriers and windows of opportunity. In G. Dosi, C. Freeman, R. Nelson, G. Silverberg, \& L. Soete (Eds.), Technical change and economic theory (pp. 458-479). London: Pinter.

Shen, Q., Feng, K., \& Zhang, X. (2016). Divergent technological strategies among leading electric vehicle firms in China: Multiplicity of institutional logics and responses of firms. Science \& Public Policy, 43(4), scv056.

Thun, E. (2006). Changing lanes in China: Foreign direct investment, local governments and auto sector development. Cambridge: Cambridge University Press.

Tushman, M. L., \& Anderson, P. (1986). Technological discontinuities and organizational environments. Administrative Science Quarterly, 31, 439-465.

von Hippel, E. (1998). "Sticky information" and the locus of problem solving: Implications for innovation. In A. Chandler et al. (Eds.), The dynamic firm (pp. 60-77). New York: Oxford University Press.

Yang, G., \& Mu, L. (2009). Reflection on the independent innovation capability in China automobile industry: Analysis through patent data (Woguo Qiche Hangye Zizhu Chuangxin Nengli de Sikao-Tongguo Zhuanli Shuju Yuyi Toushi). Intellectual Property, (3), 35-39.

Yang, L., Xu, J., \& Neuhäusler, P. (2013). Electric vehicle technology in China: An exploratory patent analysis. World Patent Information, 35(4), 305-312.

Zheng, J., Mehndiratta, S., Guo, J. Y., \& Liu, Z. (2012). Strategic policies and demonstration program of electric vehicle in China. Transport Policy, 19(1), 17-25.

Open Access This chapter is licensed under the terms of the Creative Commons Attribution 4.0 International License (http://creativecommons.org/licenses/by/4.0/), which permits use, sharing, adaptation, distribution and reproduction in any medium or format, as long as you give appropriate credit to the original author(s) and the source, provide a link to the Creative Commons license and indicate if changes were made.

The images or other third party material in this chapter are included in the chapter's Creative Commons license, unless indicated otherwise in a credit line to the material. If material is not included in the chapter's Creative Commons license and your intended use is not permitted by statutory regulation or exceeds the permitted use, you will need to obtain permission directly from the copyright holder.

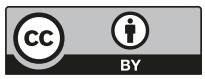

